\title{
Re-Thinking The Consumerism Phenomenon In The Liberalist- Capitalist Economic System: In a Search Of An Islamic Consumerism Model ${ }^{1}$
}

\author{
Mohd Shukri Hanapi \\ Universiti Sains Malaysia, 11800 Penang, Malaysia \\ hshukeri@yahoo.com
}

ARTICLE INFO

Article history

Received 27 January 2019

Revised 8 February 2019

Accepted 1 April 2019

Keywords

Consumerism

Wasatiyyah

Phenomenon

Economy

Conventional

\section{ABSTRACT}

In the liberalist-capitalist economic system widely applied presently, one who spends his income to maximise material utility is presumed to be something that is rational and encouraged. This is because maximum consumption of material utility is a measure of progress. However, maximising utility consumption to achieve material satisfaction could cause negative effects, especially serious debt problems and bankruptcy. This is due to consumers spending their income to maximise material satisfaction beyond their capability; thus, making them go into debt. The issue is as Muslim consumers, what is the actual level of consumption that should be practiced? Is the measurement also based on the maximum consumption of utilities such as in the liberalist-capitalist economic system mainly practiced today or is there a specific measurement that offers a unique form of consumption? In relation to this issue, this paper aimed to re-thin the consumerism phenomenon in the liberalist-capitalist economic system and explore an Islamic consumerism model, which is otherwise known as wasatiyyahconsumerism. In order to achieve this objective, this study had only explored ideas related to the wasatiyyah-consumerism model. The study found that the wasatiyyah-consumerism model applied the tawhid (monotheism) philosophy, a level of consumerism rooted in the maqasid al-syari ah component and aimed at achieving the blessings of Allah SWT.

This is an open access article under the CC-BY-SA license.

\section{Introduction}

One important element in economic activity is consumption. In the hierarchy of goods and services, consumption is the last stage after the production and distribution process. Without consumption, the production process could not take place (Fadhilah Mat Nor, et. al., 2016). Usually, discussion on consumption in conventional economics would comprise topics such as the aim of consumption, the presumption of consumption, the rationality and utility concept, the priority of the consumer's choice, consumption ethics and a balance between the consumer and the present as well as past consumption habits through the consumption function. In this matter,

\footnotetext{
${ }^{1}$ This paper would be the conference speech to be delivered at the International Conference "Rahmatan Lil "Alamiin Education”, organized by Islamic Economics and Business Lecturers Forum (FORDEBI) Politeknik Negeri Malang and Masjid Raden Patah Universitas Brawijaya, Malang. It's to be held at the Aula Pertamina, Politeknik Negeri Malang on 1-2 March 2018.
} 
society's dependence on the consumer theory built by Western economists has a great effect on consumer behaviour.

These allegations can be proven based on problems concerning economic activities such as the waste of food by Malaysians estimated to be RM4.4 trillion a year (Hishamuddin Rais, 2016); high debts as indicated by Manulife Investors Sentiments Index Study (MISI), which found 68 percent of Malaysians facing debts and placed Malaysia in the group of eight Asian markets that have a high household debt rate (Aleya Amri, 2016 \& Nur Nazlina Nadzari, 2016); and a bankruptcy issue as indicated by the Malaysian Insolvency Department, whereby 97,215 bankruptcy cases were recorded in this country from 2012 to September 2016. From that total, 22,581 cases or 23 percent involved the young-adult category or the Gen-Y, aged between 25 to 34 years old were declared bankrupt, besides 1,157 cases involved those below the age of 25 years. According to Azaddin Ngah Tasir, the Chief Executive Officer from the Agency for Counselling and Credit Management (ACCM), among the main reasons for bankruptcy was the failure to repay car hire-purchase loans (26,801 cases or 27.6 percent), followed by personal loans (22,153 cases or 22.8 percent) and housing loans $(18,819$ cases or 19.4 percent).

This was caused by the attitude of consumers themselves, especially Muslim consumers, who were not fully aware about the objectives and level of consumption from an Islamic perspective that caused them to be easily trapped in the consumption phenomenon in a liberalist-capitalist economic system.

In a liberalist-capitalist economic system, a consumer who spends his income towards maximising material satisfaction is something that is rational and greatly encouraged (Basri Abd. Ghani, Abd Aziz Harjin and Sayuti Abd. Ghani, 2008; Norliza Abdul Wahid, 2011; Nurshuhaida Abdul Razak \& Siti Zaiton Mohd Dali, 2012). This is because progress is measured by the maximum consumption of material utility. The higher the rate of consumption of material utility, the higher the level of progress achieved (Heilbroner, 1962; Bontrup, 1998; Raiklin \& Uyar, 1996:50-52; Gailbraith, 1967). Nevertheless, maximum consumption in order to achieve material satisfaction could cause negative effects such as wastage, serious indebtedness and bankruptcy. This happens when consumers with low income are forced to borrow to maximise material utility satisfaction (Norliza Abdul Wahid, 2011).

In this situation, what kind of consumption should be practiced by Muslim consumers? Is the measurement based on maximum utility consumption as in the liberalist-capitalist economic system that is much practiced now or is there a specific measurement that forms a unique type of consumerism? Hence, this study is an initiative to explore an Islamic consumerism model or otherwise known as wasatiyyah-consumerism.

Although the Malaysian government had specifically made the wasatiyyah concept the prime mover in Gagasan 1Malaysia (GIM) as well as the philosophy behind national administration policies; however, until now it has not become an approach used in consumption. The aspect of consumerism and the wasatiyyah concept are discussed separately when wasatiyyah is an approach applied in consumption. The imperfection of the consumption aspect separated from the wasatiyyah concept causes the issues mentioned earlier. This also shows an implementation that is elective and superficial in character. These elective and superficial characteristics implicate something that is implemented that contains problems related to imperfection and being uncomprehensive. The implications are that the solutions to issues pertaining to consumerism cannot materialise in a holistic fashion at the grass-roots and it is only temporary in nature.

Based on this reasoning, building the wasatiyyah-consumerism model based on objectives of maqasid al-syari'ah is an important element when facing the consumerism phenomenon in a liberalist-capitalist system. Indirectly, it would assist in confronting issues of ghuluw-consumerism (consuming according to needs and wishes based on natural inclinations).

\section{Method}

This qualitative study only used secondary data. There were two reasons for collecting secondary data. First, it was intended to investigate the conventional consumerism concept, 
Islamic consumerism concept and the wasatiyyah concept. The content analysis method was used to analyse the data collected from the secondary source, which were past studies and literature related to this study such as thesis, journals and literature related to the conventional consumerism concept, Islamic consumerism concept and the wasatiyyah concept. Second, it was intended to explore the ideas and structure of the wasatiyyah-consumerism model based on maqasid alsyari 'ah. The formation of this model was done by referring to the main sources of Islam, which is the al-Qur'an and the Hadith as well as literature related to the scriptures of interpretation, hadith, Sirah and published authoritative studies (thesis and journal articles).

To analyse the collected data, the qualitative content analysis method was used in this study. Hence, for this purpose, the researcher read texts and interpreted it according to the theme of the study. The qualitative content analysis fits this study because the researcher will study other studies and literature related to the conventional consumerism concept, Islamic consumerism concept and the wasatiyyah concept.

\section{Results and Discussion}

A review of past literature is divided into four main themes, namely conventional consumerism, Islamic consumerism, the wasatiyyah concept and the maqasid al-syari 'ah concept.

\subsection{Conventional Consumerism}

Past literature reviews about conventional consumerism were widely discussed from various perspectives, such as general discussions to specific discussions. For example, Marshall (1890) had developed an analysis for utility theory and he is said to be the founder of the utility and rationality theory. His study has become the basis for developing this theory and helped spark the capitalist economic system in Europe around the 17th to the 19th century (Kahf, 1992a). Later, Weber (1958), a sociologist, stated that the rationalistic concept in economic rationalism, such as the capitalist economic system, cannot fully explain the economic phenomenon occurring in the actual world. According to Kahf (1992b), this finding is presumed to be a study that divulged the weakness of the capitalist economic system that had applied the rationalistic concept as a basis for developing its economic theory and resulted in a new economic concept, which was the socialist economic system.

Consumer theory was also discussed by using the empirical approach from a macroeconomic aspect. Among the studies was the empirical study by A. Pollak (1969), which had introduced a new type of demand function that emerged due to several problems in the consumer theory besides discussing the consumer theory from a micro and macro-economic aspect. He found that the utility function should be based on the household production function and not the individual. This finding was however contradicted by Edward and De Donnea (1977), who found that the utility function not only depended on the level of household and individual production but was also influenced by technology and taste. All these factors are relevant in determining the household utility function (Meadows, 1997). Meanwhile, Anderson (2006) had suggested an individual consumer function that tried to maximise utility from both present and future consumptions. He found that it had an effect on the Master Plan Creation (MPC), in which the MPC decreased compared to the original MPC.

The study on consumer theory from a macroeconomic aspect continued to expand through the empirical study by Varian (1996). Varian (1996) found that savings were only done with the intention of future use. This was followed by Xiootong Jin (2008), who studied the awareness of consumers as a variable in the development model in China. Based on his analysis, it was found that the Chinese increased their consumerism awareness according to the situation and economic level of the country. Carroll (2009) investigated the effect of a sudden rise in income on consumption and the budget line. The effect was based on the ratio of increase in income and change in consumption. 
Based on previous literature reviews concerning conventional consumerism, it was found that conventional researchers were inclined to emphasise on analysing choice of consumption (microeconomy) and intertemporal consumption (macroeconomy)

\subsection{Islamic Consumerism}

Many Islamic economists are inclined to discuss this matter in a focused fashion. For example, Khaf (1992a) had discussed the intentions of a Muslim consumer regarding his consumptionrelated activities. According to Khaf (1992a), the Muslim consumer should lend priority to the afterlife (heaven) instead of worldly matters. Basically, a Muslim would face two choices, which is between using only economic goods that are worldly in nature and economic goods that have worship connotations (ukhrawi). Khaf (1992a) also mentioned that the consumption of goods for worship is more valuable compared to consumption for worldly reasons. This is because consumption is oriented towards al-falah, which is to seek the blessings of Allah SWT with the view of life in the after-life (heaven). The greater the consumption for worship the higher the value of al-falah that would be attained.

Siddiqi (1992) had also supported al-falah as the aim of Muslim consumers. According to Siddiqi (1992), the aim of achieving al-falah in this world and in the after-life is the main intention of consumers when rationalising their needs and wants so that they are in-line with the utility of their consumption.

Meanwhile, the discussion on the rationality and utility concepts also gained the attention of Islamic scholars. Among them was a study by Syed Omar Syed Agil (1990), who critically discussed the concept of rationality from Islamic and conventional perspectives. According to Syed Omar Syed Agil (1990), the consumer's rational should be separated from religion. Religious beliefs are closely related in determining a person's behaviour. Biraima (1991) outlined the Qur'anic economic theory, which integrated orthodox economy (maximising utility as a principle that determines rational choice) and Islamic economy (maximising faith as a principle that determines a Muslim's rational choice). The combination of these principles plays the role of MPC. The study found that maximising wants was inversely related to awareness of the after-life (alam baqa' or akhirat).

Mannan (1993) differed by saying that rationality in Islamic economics always takes into consideration the aspect of benefits (maslahat). The consumer should lay priority to the limitations posed by his income. According to him, this approach should be applied to all types of needs demanded by maqasid al-syari' 'ah, such as protecting the sanctity of religion, life, mind, off-spring and property.

Several studies had also investigated the rationality aspect in Islamic consumerism (Abdul Aziz Sahidin, Azizah M. Isa, Mohd Shukor Abdul Manan and Habibah Lehar, 2000, Basri Abd. Ghani, Abd Aziz Harjin and Sayuti Abd. Ghani, 2008, Norliza Abdul Wahid, 2011, and Nurshuhaida Abdul Razak and Siti Zaiton Mohd Dali, 2012). Based on these studies, it was found that in Islamic economy, consumers are presumed to be rational when they spend their income for maximising material satisfaction in-line with spiritual satisfaction. Materialistic utility would fully satisfy them in this world, while spiritual utility would satisfy them later in their after-life. Hence, income can be used, both for fulfilling materialistic and spiritual utility. For example, besides spending the income on food, clothing and other necessities, they would also want to give away some of their income as a donation to the needy. Their decisions are not just based on their own thoughts but more importantly it's based on religious values, such as Islamic values.

However, the consumerism concept in Islamic economic discussed by several authors (Abdul Aziz Sahidin, Azizah M. Isa, Mohd Shukor Abdul Manan and Habibah Lehar, 2000, Basri Abd. Ghani, Abd Aziz Harjin and Sayuti Abd. Ghani, 2008, Norliza Abdul Wahid, 2011, and Nurshuhaida Abdul Razak and Siti Zaiton Mohd Dali, 2012) was still bound by the consumerism concept from conventional economy, which is to maximise material satisfaction. The only difference was that they included the element of spiritual utility. This is termed as accommodating 
and modifying the consumerism concept in conventional economy, which is not contrary to Islamic syariat and is adopted in Islamic economy.

Something similar to this was initiated by Fadhilah Mat Nor, Aza Shahnaz Azman, Mawar Murni Yusnos and Abdul Ghafar Ismail (2016), whereby the consumer was presumed to be rational when they spent their income to maximise material satisfaction as well as spiritual satisfaction. Material utility would immensely satisfy them in this world, whereas spiritual utility would satisfy them in the after-life. In order to support this statement, they mentioned that the al-Qur'an itself stressed that pure satisfaction was the goodness obtained in this world as well as in the after-life. It is clear that a study by Fadhilah Mat Nor, Aza Shahnaz Azman, Mawar Murni Yusnos and Abdul Ghafar Ismail (2016) had still presumed that maximising material satisfaction in this world was in line with spiritual satisfaction in the after-life although verse 77 Surah al-Qasas had emphasised on spiritual satisfaction (after-life) compared to maximising material satisfaction (in the present world).

Thus, looking at other aspects, consumer's choice was also discussed by Islamic academicians. For example, Afzal-ur-Rahman (1975) had divided consumption priorities into four components such as basic necessities, goods that enhance skills, comfort goods and luxury goods. Meanwhile, Mannan (1980) and Muslehuddin (1980) had divided consumption priorities into three types such as basic necessities, comfort goods and luxury goods. However, according to Sadeq (1987), there are six types of consumption priorities, namely living needs, basic necessities, luxury goods, comfort goods, dangerous goods and goods that enhance skills.

The development of consumerism from an Islamic perspective also discussed consumer behaviour. Khan (1983) had discussed in detail about consumer behaviour from an Islamic perspective. According to him a Muslim should be ethical and follow Islamic norms when using goods and services. Muslims should lend priority to benefits (maslahah) instead of utility satisfaction to fulfil limited wants. In relation to this, Kahf (1992b) stated that there were three basic principles in consumer behaviour theory, namely belief in the after-life, the al-falah concept as well as the function and position of property.

Besides the discussions on choice and priorities of consumers, Islamic scholars are also inclined to emphasise on discussions about the function of consumption such as discussions by Western economists regarding conventional consumption theory. For example, Munawar (1985) had commented on the changes to the consumption function as a result of applying economy zakat compared to applying taxes in conventional economy. His study had supported Khaf (1984) by saying that savings without a decision to invest would only lower the consumer's indifference curve. Munawar's (1985) study was further strengthened by Khan (1990), who had given similar comments regarding the application of zakat to the consumption function by providing mathematical and flow chart examples.

Besides that, there were discussions related to etiquette and rules on consumerism in Islamic economy. For example, Noor Ashikin Hamid, Nur Amani Pauzai and Shariffah Nuridah Aisyah Syed Nong (2011) found that although consumers were given full freedom to use any goods or services for the well-being of life, the consumption was subject to etiquette and rules stipulated by Allah SWT.

Contrary to studies before this, Mohammad Aizat Jamaludin, et. al. (2012) studied Islamic consumerism from the halal perspective, which inclined more towards tenets (hukum) or the emphasises on halal haram. Besides that, it also involved the halalan tayyiban concept, producing halal products, identifying halal logos, consumerism ethics, Muslim consumer rights and legislation related to halal consumerism. The study by Mohammad Aizat Jamaludin, et.al. (2012) had differed with previous studies (Abdul Aziz Sahidin, Azizah M. Isa, Mohd Shukor Abdul Manan and Habibah Lehar, 2000, Basri Abd. Ghani, Abd Aziz Harjin and Sayuti Abd. Ghani, 2008, Norliza Abdul Wahid, 2011, Nurshuhaida Abdul Razak and Siti Zaiton Mohd Dali, 2012 and Noor Ashikin Hamid, Nur Amani Pauzai and Shariffah Nuridah Aisyah Syed Nong, 2011) because he had focused on the halal aspect.

Literature reviews on Islamic consumerism showed that many studies touched on discussions pertaining to the objective of consumption, rationality concept, consumer's choice, consumerism 
ethics as well as present and past consumption. This shows that there are still gaps that should be filled and studied such as the wasatiyyah-consumerism aspect that focuses on the level of consumption. In other words, the wasatiyyah-consumerism concept that will be built does not include elements of conventional consumerism that are not according to maqasid al-syari'ah.

\subsection{The Wasatiyyah Concept}

According to Chandra Muzaffar (2011), wasatiyyah is a complex and universal concept that cannot be easily translated into other languages. It is an Islamic philosophy that should be deeply appreciated. In the al-Qur'an, wasatiyyah is expressed using the term wasatan. The term ummatan wasatan in verse 143 Surah al-Baqarah (2) is specifically meant for Muslims. Ummatan wasatan means a moderate Muslim, one who is excellent in all aspects (Ismail Ibrahim, 2012; Zulkifli Mohamad al-Bakri, 2011 \& Mohd Shukri Hanapi, 2014), just (Chandra Muzaffar, 2011; Ali Muhammad al-Salabiy, 1999:41; Mohd Najib Abdul Razak, 2015a \& 2015b; Abdullah Md Zin, 2013:12), humble, progressive (Zulkifli Mohamad al-Bakri, 2011), the best (Mahmud Abdul Rahman, 2015:147) and balanced (Chandra Muzaffar, 2011).

Besides meaning the best, just, humble, progressive and balanced, there are several authors who have referred to ummatan wasatan as moderation. For example, Ismail Ibrahim (2012:39) mentioned that the term wasat is a term similar to moderation or equilibrium. However, the term wasat has nothing to do with moderation. They are two different terms. The term moderation was introduced by Westerners, which means 'to liberalise religious teachings'. This differs with the term wasatiyyah, which is practiced based on Islamic epistemology. Actually, the Muslims only use the term moderation so that the Westerners understand the wasitayyah concept discussed by the Muslims.

According to Zulkifli Mohamad al-Bakri (2011:15), ummatan wasatan is an appellation given by Allah SWT to Muslims. This proves that Muslims possess special characteristics that differentiates them from others and makes Muslims the best (Ali 'Imran, 3:110). The explanation about the meaning of ummatan wasatan adduced by Zulkifli Mohamad al-Bakri (2011) differs with the views of Ismail Ibrahim (2012). According to Ismail Ibrahim (2012), ummatan wasatan refers to Muslims who are dynamic, strong and progressive in form, have an agenda for the struggle that is in-line with the religion and its teachings, which are complete and comprehensive, as well as not subjects who accept only some parts of the religious teachings.

The meaning of ummatan wasatan given by Mahmud Abdul Rahman (2015:147) also differed with that adduced by Zulkifli Mohamad al-Bakri (2011) and Ismail Ibrahim (2012). According to Mahmud Abdul Rahman (2015), ummatan wasatan refers to Muslims who consistently are good Muslims as long as they protect the nature of moderation, which portrays an equilibrium and istigamah in the path of Allah SWT. Hence, Wan Kamal Mujani, Ermy Azziaty Rozali and Nor Jamaniah Zakaria (2015) stressed that today the wasatiyyah concept has been applied as a driving force in Gagasan 1 Malaysia (GIM) by the Honourable Prime Minister of Malaysia, Dato' Seri Mohd Najib bin Tun Abdul Razak. Based on this concept, all citizens are called upon to pose a balance between the spiritual and physical demands as well as between the constraints in this world and in the after-life because equilibrium and moderation are very important in creating solidarity and harmony, which then determines the success of the individual, family, society and country.

Moreover, the wasatiyyah concept adduces several basic elements that protect the harmony and creates an understanding in a multi-religious and multi-cultural society. This is because wasatiyyah is a comprehensive and integrated approach that is able to solve the demands and problems faced by the ummah (Abdullah Md Zin, 2013:13; Wan Kamal Mujani, Ermy Azziaty Rozali \& Nor Jamaniah Zakaria, 2015).

Actually, the wasatiyyah concept is an approach that is appropriate when applied to every aspect of life and becomes the basis for forming a Mukmin's personality, which would then contribute towards Islamic development. This concept is in-line with the demands of Islamic 
society, which intends to equip itself by becoming the best umat besides nurturing the relationship with Allah SWT and also among other humans (Syaidatana Siti Aishah Ab Aziz, 2014:9).

According to Mohd Ridhuan Tee Abdullah (2012), the wasatiyyah concept must be practiced in Islam so that Muslims become the best umat. Everyone can become rich but they must not forget their responsibility towards Allah SWT. They could develop but that development should not be internecine or destroy the environment.

Hanapi (2014:51) stated that the wasatiyyah concept is one of the specific characteristics of Islamic worldview (tasawur), which aims to balance or negate extreme actions in every aspect of human life. Hence, Muslims are called upon to practice moderation. This is to enhance the quality of life of humans in various aspects of life, beginning from the understanding of religion to the individual's relations with society as well as management aspects and Islamic development.

As previously explained, the wasatiyyah concept is an approach that practices Islamic teachings in a balanced and comprehensive fashion pertaining to every aspect of life. For example, it helps to enhance the ummah's quality of life in aspects such as developing knowledge, the economic system, finance, defence, human development etc. (Abdullah Md Zin, 2012:48).

The wasatiyyah concept is appropriate when applied in everyday life because Islamic society has long practiced this concept in every aspect of life (Mohd Yusof Othman, 2013). For example, the wasatiyyah concept has been practiced by Malaysians since 1957, which was after obtaining independence, mainly in issues pertaining to religion (Abdullah Md Zin, 2014:17).

According to Abdul Monir Yaacob (2015:112), wasatiyyah is a concept that exists in Islam. It has universal values that could be applied in various fields, including the consumerism aspect. This is because the wasatiyyah concept is more inclined towards shaping Muslims who have attitudes, actions as well as practices that are not extreme or inclined towards radical attitudes in every aspect of life (Ismail Ibrahim, 2012:32).

The wasatiyyah concept was chosen as an approach in consumerism because it is an approach that has the potential and capability to solve problems faced by the ummah (Abdullah Md Zin, 2013). According to Khader Ahmad, Mohd Farhan Md Ariffin, Mohd Khairi Shafie, Sedek Ariffin, Fauzi Deraman and Mustafa Abdullah (2016), the wasatiyyah concept is capable of attracting human interest in religion and this proves that Islam is a religion that disciplines its umat with tenets (hukum) and laws.

\subsection{The Maqasid al-Syariah Concept}

Basically, maqasid al-syari'ah is the reason behind the implementation of a tenet (hukum) based on syariat. This is a discipline of knowledge that becomes a yardstick when implementing something, either it is in-line with syariat Islam or not. Maqasid al-syariah is murakkab by nature or comprises two words, namely maqasid and al-syariah (Zulkifli Mohammad al-Bakri, 2014:1), with Maqasid meaning intention. In Arabic, the root word for maqasid is qasd. This word has various meanings such as leading towards, direction, walking straight, to break-up, belief, source, justice, uprightness and moderation (Ibn Manzur, 1993 \& al-Fayruz Abadi, 1997: 449). In a similar vein, Ismail al-Hasani (1995:114-115) also stated that maqsad means leading towards but the usage is more towards the language aspect. It also means moderation or an intermediate stand between two elements (Rahman, 2014:5).

Allah SWT exhorted, meaning:

"And be moderate in your pace and lower your voice; indeed, the most disagreeable of sounds is the voice of donkeys." (al-Luqman, 31:19) 
Allah SWT also exhorted, meaning:

"Then we caused to inherit the Book those We have chosen of Our servants; and among them is he who wrongs himself, and among them is he who is moderate, and among them is he who is foremost in good deeds by permission of Allah. That [inheritance] is what is the great bounty". (Fatir, 35:32)

The word syariah originated from the Arab word syara'. From a linguistic aspect, it means a straight path. Zulkifli Mohamad al-Bakri (2014) defined syariah as a form of legislation that was conveyed by Allah SWT to the Prophet SAW to be passed on to his subjects. For example, morality, food, beverage, clothing and commerce. Ibn Manzur (1993) stated that syariah means 'to explain and show the path'.

When the words maqasid and al-syariah are combined, maqasid al-syariah is formed. AlRaysuni (1996:19) defined maqasid al-syariah as the aim determined by syarak to be implemented to provide goodness to HIS subjects. Al-'Alim (1997) stated that maqasid al-syariah is the goodness obtained by the subjects, either by doing something good or abstaining from doing something prohibited. In agreement with al-'Alim (1997) was al-Qaradawi (2000), who stated that maqasid al-syariah was intended to form tenets (hukum) according to the syariat in order to enable humans to enjoy the goodness and avoid what is prohibited. The definition used in this working paper follows that made by al-Raysuni (1996:19) because the meaning is clear whereby the objectives established by syarak for humans to pursue or initiate are intended to achieve mardat Allah.

Al-Syatibi (d.u:17) and al-Ghazali (1996:139), had divided maqasid syariah into three components, namely basic needs (daruriyyah), normal needs (hajiyyah), and needs of comfort (tahsiniyyah). According to Ghilman Nursidin (2012), these components are categorised according to the level of importance. Actually, this division was earlier initiated by Imam al-Haramayn alJuwayniy. Then, this was followed by ulamak after him such as al-Ghazaliy, al-'Izz 'Abd al-Salam, al-Qarafiy, Ibn al-Taimiyyah, Ibn al-Qayyim and al-Syatibiy.

However, in a wider scale, Sadeq (1983) had divided it into five components, which were basic needs (daruriyyah), normal needs (hajiyyah), needs of comfort (tahsiniyyah), luxury needs, and dangerous or destructive goods. Thus, for the purpose of forming the wasatiyyah-consumerism concept in this paper, all five components were applied.

The discussions on the wasatiyyah-consumerism model in this paper are divided into three parts. First is the philosophy of wasatiyyah-consumerism, the second is the level of wasatiyyah-consumerism and the third is the objectives of wasatiyyah-consumerism.

\subsection{The Philosophy Behind Wasatiyyah-Consumerism}

Philosophy is the basis for policies and guidelines for any economic system (Khurshid Ahmad, 1980; Kahf, 1989:72). In this study, tawhid (monotheism) is the philosophy behind wasatiyyahconsumerism and this would help differentiate between wasatiyyah-consumerism and conventional-consumerism.

Tawhid means to surrender oneself, to submit and completely trust the oneness of Allah SWT (al-Qaradawi, 1995:31; al-Ikhlas, 112:1-3). The trust and confidence includes the affirmation that Allah SWT is the absolute Creator, Owner and Controller of this world (Tawhid Rububiyyah) and affirm that it is compulsory to worship and pay allegiance to only Allah SWT (Tawhid Uluhiyyah) (Sardar, 1990; al-Qaradawi, 1995; Khalijah, 2011). Hence, a strong tawhid would be able to successfully implement Syariah and moral values. This means that all activities would fall into a framework that designs life according to the wishes of Allah SWT. In the consumerism context, it would design a consumerism system that signifies not only material satisfaction and neglect the spiritual context aspect. 
It is clear here that tawhid is the most basic element in a Muslim's way of life and occupies the most important position in a man's life (Surtahman Kastin Hasan, 2011). It is the pillar or core to all aspects of human life, generally and consumerism activities, specifically (Abdul Halim Abd Kadir, Nor Azzah Kamri \& Baharom Kassim, 2013). The tawhid approach not only helps fulfil individual needs in the preparation of all forms of planning in their life in a comprehensive manner but also focuses on responsibility of humans created in this world, which is to worship Allah SWT.

\subsection{The Level of Wasatiyyah-Consumerism}

Wasatiyyah-consumerism could be realised when consumers spend their income according to needs and not to maximise their materialistic satisfaction such as in the liberal-capitalist system. Thus, before realising wasatiyyah-consumerism, the levels have to be firstly established. In this study, building the levels of wasatiyyah-consumerism was based on the components in the maqasid al-syari'ah, which is daruriyyah (basic/life needs), hajiyyah (additional needs), tahsiniyyah (complimentary/convenience needs), kamaliyyah (luxury needs) and dangerous or destructive goods.

Consumption for Daruriyyah Needs, this refers to a consumption that fulfils all of life's needs or the basic needs of man by adhering to five elements (daruriyyat al-khams) such as religion, life, mind, property and family linage. Thus, consumerism that is necessary for life is like using a sum of money to buy food and beverage for the benefit of life (al-Baqarah, 2:35); buy clothing for the benefit of religion and self-respect (al-A'raf, 7:26); provide accommodation or a dwelling for the benefit of life (al-Syu'ara', 26:128-129); pay the costs of education to fulfil the benefits of the mind; and the need to obtain medication for the benefit of life. Consumerism intended to fulfil the basic needs of life is very important because of maqasid daruriyyah. These are the benefits that determine the balance between a religious life and human life based on worldly matters. Thus, if this element is not fulfilled, human life would be miserable and the joy would be lost forever.

Consumption for Hajiyyah Needs, this refers to the consumption of money to obtain something that is not related to the basic needs of humans but it is an additional need that is needed to facilitate their lives and give them a comfortable life. When the need for hajiyyah is not met, it would not jeopardise human life but it could lead to difficulties and a harsh life. Expenditure on the needs of hajiyyah are usually carried out after the needs of daruriyyah have been fulfilled. The consumption of the needs under hajiyyah are permitted in situations such as taking a car loan to facilitate life and fulfil a wish according to one's capability. Besides that, loans that lead towards the possession of comforts of a home, clothing and food are permitted because it causes one to be happy and enhance working capabilities. Moreover, syarak has given the freedom for humans to enjoy it. Nevertheless, Muslims are advised not to over-do it until it causes wastage because this would lead to the loss of noble virtues (al-Furqan, 25:67).

Consumption for Tahsiniyyah Needs, the tahsiniyyah needs have a cosmetic effect on life. With its presence, human life becomes even better. Its absence would not trouble human life or cause distress but human life would be void of esteemed values that are demanded by honour and general etiquette of a civilised society. Hence, if these virtues are not nurtured there would be negative effects on life. The al-Qur'an has instructed Muslims to enjoy what is good and beautiful. For example, by being in debt is allowed if it is with the intention of having a wedding and completing the akad nikah ceremonies, to buy a car if there is a need and capability or to own a suitable house with beautiful decorations and fittings because all these reflect the characteristics of serenity and happiness that is permitted in Islam (al-A'raf, 7:32). Enjoying comforts in life are allowed in Islam. Islam itself recognises the natural wants of humans who wish beauty and elegance as well as general goodness. Hence, these wants or wishes should not be extreme or wasteful. The division of these needs was done in purpose by the ulamak to assist Muslims to determine their priorities when initiating allegiance in their lives.

Consumption of Luxury Needs, this refers to the consumption of elements that are not needed for comfort but usually for prestige or showing-off. The expenditure to obtain these luxuries is usually bigger than the benefits to be enjoyed. One would become indebted just to buy an expensive car, which is an item only used or owned by the rich. In order for the medium or lowincome consumers to own items like this would entail huge debts or high payments. Since luxury 
goods are usually symbols of position, especially in the materialistic society of today, these goods have become an addiction. Generally, these luxury goods are not encouraged because it would create snobbish attitudes and submitting to natural inclinations ( $n a f s u$ ) would only be detrimental to Muslims.

Therefore, going into debt to obtain luxury items is prohibited in Islam because the consumption of luxury goods is akin to poison that slowly kills. It would surely destroy oneself, the family and society, such as the practice of corruption, incompetence at work and bankruptcy that has affected the Gen Y today.

Jon Hanson (2005) also agreed to this and aligned debt to cholesterol, in which debt incurred to obtain luxuries in life would entail problems to the individual and could even end in death. Actually, there is some truth in what was said by Jon Hanson (2005). Criminal cases related to 'along' (illegal money lenders) such as threats, suicides etc. are among the negative effects that arise due to the habit of going into debt solely to own luxuries.

Consumption of Dangerous and Destructive Goods, this refers to consumption to obtain items that are dangerous, either to the consumer or to society. Consumption such as this is prohibited. For example, borrowing in order to open a business dealing with intoxicating items and those that destroy noble virtues such as drugs, liquor and gambling dens. This is prohibited in Islam because it could cause harm to the consumer and society, besides causing the loss of sensibility, reasoning and unwarranted actions as well as wide spread social ills.

Moreover, it is also prohibited to open vice dens because Islam prohibits all types of relations based on vice except legalised marriage. This shows that Islam protects the sanctity of Muslims from matters that bring about destruction (al-Isra', 17:32). In relation to this, going into indebtedness to own dangerous and destructive goods is prohibited in Islam because it has a negative effect and is dangerous to the individual and society.

\subsection{The Aim of Wasatiyyah-Consumerism}

There are two objectives of wasatiyyah-consumerism, namely to achieve goodness and the blessings of Allah SWT. The aim of consumerism activities is to achieve well-being in life. Thus, well-being in the conventional economy context is measured based on how much (level) an individual satisfies his various needs through goods and services (Basri Abd. Ghani, Abd Aziz Harjin \& Sayuti Abd. Ghani, 2008). Allah SWT has clearly reminded those who only focus on materialistic aspects (Yunus, 10:7-8 \& Hud, 11:15-16), which refers to those who only lay importance on materialistic satisfaction without considering spiritual satisfaction.

Thus, it is clear here that well-being or actual satisfaction is only the goodness obtained in this world and in the after-life (heaven). Consumers are presumed to be rational when they spend their income on materialistic satisfaction according to needs (not unlimited wants) in-line with spiritual satisfaction. Material utility would enable the consumer to achieve goodness in this world, while spiritual utility would enable them to achieve well-being in the after-life (heaven).

When every good practice is carried out with total tawhid, sincerity and adherence to the syariat delivered by the Prophet SAW, it is blessed by Allah SWT. Consequently, after obtaining the blessing of Allah SWT, a subject would obtain al-falah in this world and in the after-life.

It is summarised here that the blessings of Allah SWT is the final objective of all of humankind's endeavours, including consumerism activities. The effect of this is that humankind would also obtain al-falah as the end. Therefore, in order to obtain the blessings of Allah SWT, humankind needs to fulfil three main conditions. First, consumerism must be implemented in total sincerity in the name of Allah SWT and steadfast in practicing tawhid. Second, to adhere to the conditions or terms set by Allah SWT and delivered by the Prophet SAW, with full appreciation and commitment in practice. Third, to always practice goodness, either when relating to Allah SWT or amongst humans (Muhammad Syukri Salleh, 1993). This is clearly different with the objective of conventional consumerism, which only lays importance on gains as well as well-being in this world. 


\section{Conclusion}

Based on the overall discussions in this study, it was found that the wasatiyyah-consumerism model is a realistic and comprehensive consumerism model. It consists of three elements. First, tawhid as its term of philosophy; second, the level of waatiyyah-consumerism that is rooted to the components of maqasid al-syari'ah, which is daruriyyah, hajiyyah, tahsiniyyah, kamaliyyah, as well as dangerous and destructive goods; and third, to achieve goodness and blessings from Allah SWT as the aim of wasatiyyah-consumerism.

Building the wasatiyyah-consumerism model is extremely significant because it delivers Muslims from further practicing conventional consumerism that dominates the liberalist-capitalist system. At the same time, it would assist society to manage their finances well, which is to spend according to priorities and capability as well as avoid attitudes such as being frugal, wasting and unnecessary spending. This kind of practice would create financial stability and harmony in life for an individual, family, society and country.

Besides that, consumption in the form of debt based on the wasatiyyah-consumerism model would result in good debts, which is debts that are beneficial and bring about well-being in life such as debts for the purpose of education or business. On the contrary, debt that is not based on maqasid al-syari 'ah would result in unwanted debts or debts that are a burden. Eventually it would entrap that individual in a financial crisis until that person becomes a bankrupt.

Islam offers freedom to its subjects to enjoy life in a proper and comfortable manner. Although this freedom is afforded, Islam prohibits its subjects from consuming solely luxurious and unnecessary goods. Hence, when incurring debts the priorities should be arranged according to maqasid al-syari 'ah, which is daruriyyah, then followed by hajiyyah, tahsiniyyah, kamaliyyah, and lastly, dangerous and destructive goods. Thus, if maqasid al-syari'ah is neglected when consuming, especially debts, then there would shortcoming in life mainly from the economic and social aspects such as bankruptcy cases.

Although there are innumerable things that we wish in life, we should be wise in managing daily finances by differentiating debts for necessities or needs from debts solely for wants. This would make a person avoid extravagance that could forge serious financial problems for the debtor.

\section{Acknowledgment}

This paper is part of the research findings entitled The Development of Wasatiyyah-Based Consumerism (203.CISDEV 6711588), which was financed by the Fundamental Research Grant Scheme (FRGS) Phase 1/2017. Special appreciation is owed to Ministry of Higher Education Malaysia (MOHE) and Universiti Sains Malaysia (USM) for sponsoring and supporting this research.

\section{References}

Abdul Aziz Sahidin, Azizah M. Isa, Mohd Shukor Abdul Manan \& Habibah Lehar (2000). Teori penggunaan menurut perspektif Islam, in. Ghafarullahhuddin Din et. al. (eds.), Ekonomi Islam. Shah Alam, Selangor: Biroteks Universiti Teknologi MARA.

Abdul Halim Abd Kadir, Nor Azzah Kamri \& Baharom Kassim. (2013). Maqasid Syariah: Isu-isu kepenggunaan, realiti dan cabaran, in Abdul Karim Ali \& Mohd Nazri Chik (eds.), Maqasid Syariah isu-isu kepenggunaan: Realiti dan cabaran. Selangor: Persatuan Ulamak Malaysia.

Abdul Monir Yaacob. (2015). Manhaj wasatiyyah dalam pelaksanaan hukum di Malaysia, in Mohd Yusuf Din (eds.), Penghayatan wasatiyyah dalam kerangka maqasid syariah. Putrajaya: Institut Wasatiyyah Malaysia (IMW).

Abdullah Md. Zin. (2012). Pendekatan Wasatiyyah Dalam Menghayati 1 Malaysia. Kuala Lumpur: Kasturi Jingga Corporation Sdn. Bhd. 
Abdullah Md. Zin. (2013). Pendekatan Wasatiyyah: Definisi, Konsep dan Pelaksanaan. Putrajaya: Institut Wasatiyyah Malaysia (IMW).

Abdullah Md. Zin. (2014). Penghayatan Wasatiyyah Dalam Pentadbiran Malaysia. Putrajaya: Institut Wasatiyyah Malaysia (IMW).

Afzal-ur-Rahman. (1974). Economic doctrine of Islam. Vol. 2. Lahore, Pakistan: Islamic Publication Ltd.

Al-'Alim, Yusuf Hamid. (1997). Al-Maqasid al-syari'at al-Islamiyyat. Al-Khartum: Dar alSudaniyyat.

Aleya Amri. (2016). 68 Peratus Rakyat Malaysia Hutang Tinggi. Retrieved July 20, 2016, from https://www.google.com.my/node 130350/amp.

Al-Fayruz Abadi, Muhammad Ibn Ya'qub al-Fayruz Abadi. (1997). Al-Qamus al-Muhit. Beirut, Lubnan: Dar al-Kutub al-'Alamiyyah.

Ali Muhammad al-Salabiy. (1999). Al-Wasatiyyah fi al-Qur'an al-Karim. 'Amman, Jordan: Dar alNafa'is.

Al-Qaradawi, Yusuf. (1995). Al-hayah al-rabbaniyyah wa al-ilm. Kaherah, Mesir: Maktabah Wahbah.

Al-Qaradawi, Yusuf. (2000). Kemiskinan dan cara Islam mengatasinya (Musykilat al-Fiqr wa kayfa 'alijuha al-Islam), terj. Arsil Ibrahim. Kuala Lumpur: Yayasan Pembangunan Ekonomi Islam Malaysia (YPEIM).

Al-Raysuni, Ahmad. (1996). Nazariyyat al-maqasid 'inda al-Imam al-Syatibiy. Riyad: Dar al'Alamiyyat li al-Kitab al-Islamiy.

Al-Syatibi. (t.t). Al-Muwafaqat fi usul al-ahkam. Beirut: Dar al-Ma'rifah.

Basri Abd. Ghani, Abd Aziz Harjin \& Sayuti Abd. Ghani (2008). Konsep Penggunaan dari Perspektif Ekonomi Islam. Paper presented at Seminar Keusahawanan Islam II Peringkat Kebangsaan 2008, organised by Akademi Pengajian Islam Universiti Malaya, 15 Oktober 2008 .

5. Biraima, M.E. (1991). Qur'anic model for a universal economic theory. JKAU: Islamic Econ., Vol. 3, p. 3-41 (1411 A.H./1991 A.D.

Bontrup, H.J. (1998). Volkswirtschaftslehre. Munich, Germany: R. Oldenbourg Verlag.

6. Carroll, P. (2009). Articulating theories of states and state formation. Journal of Historical Sociology, Vol. 22, Issue 4, December 2009, p. 553-603

Chandra Muzaffar. (2011). Prinsip Wasatiyyah Jadi Teras Gagasan IMalaysia: Masyarakat Majmuk Perlu diberi Kesedaran Mengenai Kepentingan, Keadilan, Keseimbangan. Retrieved Dec 14, 2016, from http://www.bharian.com.my /articles/

Fadhilah Mat Nor, Aza Shahnaz Azman, Mawar Murni Yusnos \& Abdul Ghafar Ismail (2016). Epistemologi Tauhid Dalam Pemikiran Ekonomi: Teori Penggunaan. Paper presented at International Conference on Aqidah, Dakwah \& Syariah (IRSYAD 2016), at Grand Blue Wave Hotel, Shah Alam, 10 May 2016.

Gailbraith, J.K. (1967). The New Industrial State. London, UK: Pelican Books.

Ghilman Nursidin. (2012). Konstruksi pemikiran maqāṣid al-syari'at Imam al-Haramayn alJuwayniy (Kajian Sosio-Historis). Post-graduate thesis, Institut Agama Islam Negeri (IAIN) Walisongo, Semarangan, Indonesia. Unpublished. 
Hal R. Varian, H.R. (1996). What use is economic theory? in Steven Medema (ed.), Foundations of Research in Economics: How do Economists Do Eco-nomics?. United Kingdom: Edward Elgar.

Heilbroner, R.L. (1962). The Making of Economic Society. Englewood Cliffs, New Jersey, USA: Prentice-Hall.

Hishamuddin Rais. (2016). Pembaziran Makanan di Malaysia Sangat Tinggi. Retrieved July 20, 2016, from http://m.utusan.com.my/bisnes/ekonomi/rakyat-malaysia-paling-ramaiberhutang-1.196814.

Ibn Manzur, Abi al-Fadl Jamal al-Din Muhammad bin Mukram al-Afriqiy al-Misriy. (1993). Lisan Al-'Arab. Jld. 11. Beirut, Lubnan: Maktabah Tahqiq Al-Turath.

Ismail Al-Hasani. (1995). Nazariyyat al-maqasid 'inda al-Imam Muhammad al-Tahir Ibn al'Asyur. Virginia: International Institute of Islamic Thought.

Ismail Ibrahim. (2012). Wasatiyyah dan Masyarakat Pelbagai Kaum di Malaysia, in Muhammad Mustaqim Mohd Zarif (ed.), Islam dan Wasatiyyah. Nilai, Negeri Sembilan: Universiti Sains Islam Malaysia.

Jon Hanson (2005). Good debt, bad debt: Knowing the difference can save your financial life. New York: Penguin Group.

Kahf, M. (1989). Islamic economics system: A review, in Aidit Ghazali \& Syed Omar (eds.), Reading concept and methodology ofislamic economics. Petaling Jaya: Pelanduk Publications.

Kahf, M. (1992a). A Contribution to the Theory of Consumer Behaviour in an Islamic Society. Studies in Islamic Economic, International Centre for Research in Islamic Economics KAAU, Jeddah, p. 19-36

Kahf, M. (1992b). The Theory of Consumption, in Sayyid Tahir et. al. (eds), Readings in Microeconomics: An Islamic Pespective. Petaling Jaya, Selangor: Longman Malaysia Sdn. Bhd.

Khader Ahmad, Mohd Farhan Md Ariffin, Mohd Khairi Shafie, Sedek Ariffin, Fauzi Deraman \& Mustafa Abdullah. (2016). Penekanan aspek wasatiyyat bagi pembangunan kesejahteraan masyarakat Islam melalui pengubatan alternatif Islam: pengalaman di Malaysia. Retrieved October 26, 2016, from http://www.academia. edu/21494290/.

Khalijah Mohd Salleh. (2011). Sains tauhidik \& implikasi terhadap pendidikan, in Khalijah Mohd Salleh (ed.), Pendidikan sains berteraskan tauhid. Bangi, Selangor: Institut Islam Hadhari, Universiti Kebangsaan Malaysia (UKM).

7. Khan, M. F. (1992). Thoery of consumer behaviour in an Islamic theory of consumer, in Readings in Microeconomics: An Islamic Pespective. Petaling Jaya, Selangor: Longman Malaysia Sdn. Bhd.

Khurshid Ahmad. (1980). Economic development in an Islamic framework, in Khurshid Ahmad et al. (eds.), Studies in Islamic economic. Jeddah: International Centre for Research in Islamic Economics King Abdul Aziz University, Jeddah \& The Islamic Foundation, United Kingdom.

Mahmud Abdul Rahman. (2015). Wasatiyyah di Arab Saudi: manhaj dan pelaksanaan, in Mohd Yusuf Din (ed.), Penghayatan Wasatiyyah Dalam Kerangka Maqasid Syariah. Putrajaya: Institut Wasatiyyah Malaysia.

Marshall, A. (1890). Principles of economics. London: Macmillan and Co. 
Meadows, E. (1977). The New and Improved Consumer Behavior Theory, Studies in Economics and Finance, Vol. 1 Issue 1, p.16-27, https://doi.org/10.1108/eb028586

Mohammad Aizat Jamaludin, Mohd Anuar Ramli, Mariam Abdul Latif \& Dzulkifly Mat Hashim Suhaimi Ab Rahman (2012). Pendidikan kepenggunaan halal di Malaysia, in. Norarfan Zainal et al. (eds.), Membongkar Rahsia Pendidikan Islam. Bandar Seri Begawan: Kolej Universiti Perguruan Ugama Seri Begawan, p. 285-289.

Mohd Anuar Ramli \& Mohammad Aizat Jamaludin. (2012). Pengenalan kepenggunaan Islam. Retrieved December 15, 2013, from http://www.academia.edu/4350011/ Pengenalan_kepenggunaan_Islam.

Mohd Najib Abdul Razak. (2015a). Memartabatkan Wasatiyyah. Putrajaya: Institut Wasatiyyah Malaysia (IMW).

Mohd Najib Abdul Razak. (2015b). Pelaksanaan Menyeluruh Wasatiyyah. Putrajaya: Institut Wasatiyyah Malaysia (IMW).

Mohd Ridhuan Tee Abdullah. (2012). Memahami wasatiyyah, in Koleksi artikel pilihan sempena Seminar Pemahaman Wasatiyyah dan IMalaysia. Kuala Lumpur: Sekretariat Seminar Pemahaman Wasatiyyah dan 1Malaysia.

Mohd Shukri Hanapi. (2014). Tasawur Islam dan Pembangunan. Kuala Lumpur: Dewan Bahasa dan Pustaka.

Muhammad Syukri Salleh (2013). 7 Prinsip Pembangunan Berteraskan Islam. Kuala Lumpur: Zebra Editions Sdn. Bhd.

Noor Ashikin Hamid, Nur Amani Pauzai \& Shariffah Nuridah Aisyah Syed Nong (2011). Konsep Kepenggunaan Mengikut Syariah dan Aplikasinya Dalam Undang-Undang Malaysia. Jurnal Kanun Undang-undang Malaysia, Vol.1, June 2011, Universiti Darul Iman Malaysia, Terengganu.

Norliza Abdul Wahid. (2011). Penggunaan dalam konteks ekonomi islam dan perbandingan dengan ekonomi konvensional. Project paper Faculty of Economics and Administration. Kuala Lumpur: Universiti Malaya.

Nur Nazlina Nadzari. (2016). Rakyat Malaysia paling ramai berhutang. Retrieved July 20, 2016, from http://www.mstar.com.my/lain-lain/rencana/2016/05/30/pembaziran-makanan/.

Nurshuhaida Abdul Razak \& Siti Zaiton Mohd Dali. (2012). Perbezaan analisis kepenggunaan menurut ekonomi konvensional dan ekonomi Islam. Paper presented at Persidangan Kebangsaan Ekonomi Malaysia ke-VII (PERKEM VII), Ipoh, Perak, 4-6 Jun 2012.

8. Pollak, R.A. (1969). Conditional Demand Functions and Consumption Theory, The Quarterly Journal of Economics, 1969, Vol. 83, Issue 1, p. 60-78.

Raiklin, E., \& Uyar, B. (1962). On the Relativity of the Concepts of Needs, Wants, Scarcity and Opportunity Cost. International Journal of Social Economics, 23(7), 49-56.

Sardar, Z. (1990). Masa Hadapan Islam (Islamic Future: The Shape of Ideas to Come), translated by Mohd Siden Ahmad Ishak. Kuala Lumpur: Dewan Bahasa dan Pustaka (DBP).

Siddiqi, M.N. (1992). Islamic Consumer Behaviour, in Readings in Microeconomics: An Islamic Pespective. Petaling Jaya, Selangor: Longman Malaysia Sdn. Bhd.

Surtahman Kastin Hasan. (2011). Ekonomi Islam Pengenalan. Selangor: Universiti Kebangsaan Malaysia.

Syaidatana Siti Aishah Ab Aziz. (2014). Konsep Wasatiyyah Dalam Gagasan 1Malaysia: Analisis Berdasarkan Tafsiran Ayat 143 Surah Al-Baqarah. Master Dissertation (M.Soc-Islamic 
Development Management), Centre for Islamic Development Management (ISDEV), Universiti Sains Malaysia, Penang. Unpublished.

9. Syed Omar Syed Agil (1992). Rationality in Economic Theory, in Readings in Microeconomics: An Islamic Pespective. Petaling Jaya, Selangor: Longman Malaysia Sdn. Bhd.

Wan Kamal Mujani, Ermy Azziaty Rozali \& Nor Jamaniah Zakaria. (2015). The wasatiyyat (moderation) concept: Its implementation in Malaysia. Mediterranean Journal of Social Sciences, 6(4), 66.

Weber, M. (1958). From Max Weber: Essays in sociology. New York : Oxford University Press.

Zaharuddin Abd Rahman. (2014). Fiqh kewangan Islam: halal dan haram dalam sistem jual beli Islam. Selangor: PTS Islamika Sdn. Bhd.

Zulkifli Mohamad al-Bakri. (2011). Wasatiyyah Konsep dan Pelaksanaan. Kuala Lumpur: Yayasan Dakwah Islamiah Malaysia.

Zulkifli Mohamad al-Bakri. (2014). Maqasid al-Syari'at: Satu Pengenalan Umum. Negeri Sembilan: Pustaka Cahaya Kasturi. 